\title{
Acil Servislerde Kullanılan Sarf Malzemelerin ABC ve VED Yöntemiyle Analizi: Bir Özel Hastane Örneği
}

\author{
Analysis of Consumables Used in Emergency Departments by ABC and VED Method:
}

\author{
A Private Hospital Example
}

Ercan ÇULHA ${ }^{1}$, Zekai ÖZTÜRK ${ }^{2}$

\section{ÖZ}

Sağl1k işletmeleri hizmet sunumu sırasında ihtiyaç duydukları her türlü ilaç ve tıbbi malzeme için gerekli olan finans kaynağını etkili bir şekilde yönetmeleri gerekmektedir. Çünkü sağlık işletmeleri ilaç ve tıbbi malzeme alımlarında toplam bütçelerinin yaklaşık üçte birini kullanmaktadır. Bu çalışmanın amac1, Ankara'da bir özel hastanenin acil servis bölümünde kullanılan 2019 yılına ait tıbbi sarf malzeme tüketimlerini tespit etmek ve stoklardaki malzemelerin ABC-VED analizi ve ABC-VED matris analiziyle harcama tutarını ve miktarını analiz etmektir. Yapılan analiz sonuçlarına göre; $\mathrm{ABC}$ analizi ile A grubunda yer alan toplam malzemeler

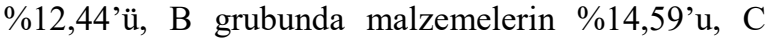
grubunda ise malzemelerin \%73'lük kısmını kapsadığı tespit edilmiştir. VED analizi ile malzeme miktarlarının dağılımı V grubu $\% 45,40$, E grubu $\% 36,75$ ve $\mathrm{D}$ grubu malzemeler ise $\% 17,85$ olarak belirlenmiştir. ABC-VED matris analizi ile kategori I' e ait olan malzemelerin \%47,03'ü, kategori II ise malzemelerin \%37,30'luk k1smın1, kategori III malzemelerin \%15,67'sini kapsadığı tespit edilmiştir. Sonuç olarak ABC, VED ve ABC-VED Matris analizinin sağlık işletmelerinde kullanılması, stok maliyetlerinin en aza indirilmesi ve malzemelerin sinıflandırılması ile stok kontrollerinin yapılmasına yardımcı bir araç olarak kullanılabilecektir.

Anahtar kelimeler: Hastane, Stok Yönetimi, Malzeme Yönetimi, ABC Analizi, VED Analizi.

\section{ABSTRACT}

Healthcare enterprises must effectively manage the financial resources required for all kinds of medicines and medical supplies they need during service delivery. Because healthcare enterprises use approximately one-third of their total budget for the purchase of medicines and medical supplies. This study aims to determine the consumption of medical consumables used in the emergency department of a private hospital in Ankara in 2019 and to analyze the amount of spending and amount with ABC-VED analysis and ABC-VED matrix analysis of the materials in the stocks. According to the analysis results; With $\mathrm{ABC}$ analysis, it was determined that the total materials in the A group contain $12.44 \%, 14.59 \%$ of the materials in the B group, and $73 \%$ of the materials in the $\mathrm{C}$ group. With VED analysis, the distribution of material amounts was determined as $45.40 \%$ for V group, $36.75 \%$ for E group and $17.85 \%$ for group D. With the ABC-VED matrix analysis, it was determined that the materials belonging to category I cover $47.03 \%, 37.30 \%$ of the materials in category II, and $15.67 \%$ of the category III materials. As a result, the use of $\mathrm{ABC}, \mathrm{VED}$ and $\mathrm{ABC}-\mathrm{VED}$ Matrix analysis in healthcare enterprises can be used as an auxiliary tool to minimize stock costs and classify materials and control inventory.

Keywords: Hospital, Stock Management, Material Management, ABC Analysis, VED Analysis.

\footnotetext{
Bu çalışma birinci yazarın yüksek lisans tezinden üretilmiştir. Kurumdan Etik Kurul Onay izni (2019/33) alınmıştır.

${ }^{1}$ Doktora Öğrencisi, Sağlık Yönetimi, Sakarya Üniversitesi İşletme Enstitüsü, ercan.culha@ ogr.sakarya.edu.tr, ORCID: 0000-0001-69324917

${ }^{2}$ Prof. Dr., Sağlık Yönetimi, Ankara Hacı Bayram Veli Üniversitesi İktisadi ve İdari Bilimler Fakültesi, zekai.ozturk@hbv.edu.tr, ORCID: 0000-0003-2569-7249 


\section{GİRIŞ}

Ülkemizde sağlık işletmeleri sağlık hizmeti sunan, bireylerin kendilerini iyi hissetmelerini sağlayan veya toplum sağlığını korumayı ve geliştirmeyi kendine hedef edinen kurum ve kuruluşlardır. Sağlık işletmeleri bu hedefleri doğrultusunda kaliteli ve verimli bir şekilde hizmet sunabilmek için tıbbi malzeme ve cihazlara ayrilan finans kaynağını da etkili bir biçimde kullanması gerekmektedir. Çünkü hastaneler tıbbi malzeme ve cihaz alımlarında toplam bütçelerinin yaklaşık üçte birini kullanmaktadır. $\mathrm{Bu}$ nedenle, sağlik işletmelerinin malzeme ve cihaz maliyetlerini ve kullanımlarını etkili bir şekilde yönetmesi kurumun hem verimliliğini hem de karlılık düzeyini artırmasında etkili olacaktır.

İşletmenin karlılığ 1 ve verimliliği acısından malzemelerin etkili bir şekilde kullanılması ve maliyetin azaltılması için iyi bir malzeme yönetim sisteminin olması gerekmektedir. İyi bir malzeme yönetim sistemi içinde yer alan fonksiyonların koordineli bir şekilde faaliyete geçmesi gerekmektedir. $\mathrm{Bu}$ fonksiyonlar ihtiyaçların belirlenmesi, kaynağın saptanması ve satın alınması, taşıma, kontrolü, depolanması ve dağıtıma kadar olan sürecin etkin ve verimli bir şekilde yönetilmesi zorunludur.

Bir sağlık işletmesinde talebin değişmesi ve hem talep edilen hizmetin hem de sunulan hizmet miktarının önceden belirlenememesinden ve sağlik hizmetinin acil ve ertelenemez olmasindan dolayı hizmeti alan hastalara yapilan ya da yapılacak olan işlemlerde kullanılan her türlü malzemenin her zaman ihtiyaç duyulabilir ve kullanılabilir durumda hazır bulundurulması önem arz etmektedir. Çünkü herhangi bir tedavi sürecinde ihtiyaç duyulan malzemenin olmamas1 hastalara verilen hizmetin aksaması anlamına gelir ve bu süreçte oluşabilecek herhangi bir hata doğrudan ölümle sonuçlanabilir ya da bu süreçte hastanenin kalitesi düşebilir ve gelen hasta sayılarında azalmalar ortaya çıkabilir. Bundan dolayı hastane yönetiminin ve ilgili birimlerin bu sürece öncelik vermesi gerekmektedir.
Bu çalışmanın amacı; Ankara'da bir özel hastanenin acil servis bölümünde kullanılan 2019 y1lina ait tıbbi sarf malzeme tüketimlerini belirlemek ve tıbbi sarf stoklarındaki malzemelerin ABC-VED analizi ve ABC-VED matris analiziyle harcama tutarını ve miktarını tespit etmektir.

$\mathrm{Bu}$ analizler kapsamında, kurumun stoklarının doğru bir şekilde takibinin yapılması ve yönetilmesi, stoklardaki kayıplar, eksilmeler, deforme olmuş ve son kullanma tarihi geçmiş malzemeler gibi oluşabilecek düzensizliklerin önlenmesi, malzemelerin tüketim miktarlarının en aza indirilmesi, ihtiyacin üstünde malzeme alımlarının giderilmesi ve malzeme maliyetlerinin analiz edilmesi hedeflenmektedir.

\section{Hastanelerde Stok Yönetimi, Amacı ve Önemi}

Stok yönetimi, her türlü malzemenin tüketiciye ulaştırılması bu sürecin planlanmas1, organize edilmesi ve denetiminin yapılmasını içeren bir süreçtir. ${ }^{1}$ Başka bir tanımda ise; üretim sırasında ya da hizmet sunumunun tamamlayic1 olan hammaddelerin, yarı mamullerin ve üretim için gerekli olan diğer malzemelerin nereden tedarik edileceğinin belirlenmesi, satın alınması, depolanmasına ilişkin faaliyetlerin organize edilmesi ve kontrolü olarak bilinmektedir. $^{2}$ Stok yönetimi, stokların bir kuruluş içine ya da kuruluş içinden kuruluş dışına akışı ile ilgili faaliyetleri planlama, koordine etme ve kontrol etmeyi içerir. ${ }^{3}$

Stok yönetiminin temel amaçları ise aşağıdaki gibi sıralanabilmektedir: ${ }^{4}$

- Verimli ve sorunsuz üretim süreci,

- Kârlılığı en üst düzeye çıkarmak için optimum stok seviyesini korumak,

- Malzemelerin mevsimsel taleplerini karşılamak,

- Gelecekte fiyat artışını önlemek,

- Gerekli stokların seviyesini ve yerini temin etmek,

- $\quad$ Ne zaman ve nerede satın alacağınızı planlamak, 
- Hem maksimum hem de minimum stoktan kaçınmaktır.

Stok yönetiminde stok miktarının ve zamanının sistemli bir şekilde yönetilmesi, stok seviyelerini ve hareketlerini sürekli olarak kontrol edilmesi gerekmektedir. Stok kontrolünde sipariş hakkındaki gerekli tüm bilgileri verdikten sonra yönetimin siparişle ilgili daha uygun ve doğru kararlar almasında önemli rol üstlenmektedir. ${ }^{5}$

Sonuç olarak işletmenin yapacak olduğu herhangi bir faaliyet sirasinda en uygun kararların alınması, talep tahmini ile ihtiyacı karşlayacak malzeme miktarının belirlenmesi, kullanılmasi planlanan kaynakların maliyetlerinin en aza düşürülmesi, maliyetlerin sınıflandırılması ve maliyet tahmini yapılabilmesi, işletme kârının ve değerlerinin yükseltilmesi için gerekli olan stok yönetimi, işletmenin amaç ve hedeflerine ulaşmasında önemli bir paya sahiptir.

\section{Literatür Taraması}

Literatürde ABC - VED analizi ile ilgili yapılmış birçok çalışma bulunmaktadır. Bu çalışmalar aşağıda sırayla verilmiştir.

Devnani ve arkadaşları (2010), Hindistan'ın Chandigarh kentindeki Tip Eğitimi ve Araştırma Enstitüsü'nün (PGIMER) eczane bölümünü $\mathrm{ABC}$ ve $\mathrm{VED}$ analizi, sıkıyönetim kontrolü gerektiren malzeme kategorilerini belirlemek amaciyla yapılmıştır. 2007-2008 yılında kullanılan eczanenin her bir kalemi için yapılan yıllık tüketim ve harcamalar analiz edilerek ABCVED analizleri ve ABC-VED matris analizi uygulanmıştır. Eczanenin ilaçları 421 kalemden oluşmaktadır. Toplam yıllık ilaç harcamas1 40,012,612 rupidir. ABC analizi göre, ilaçların \%13,78 (58)'ini ve toplam maliyetin \%69,97'sini A grubu ilaçların $\% 21,85$ (92)'ini ve toplam maliyetin $\% 19,95$ 'ini B grubunu ve ilaçların \%64,37 (271)'sini ve toplam maliyetin \%10,08'ini C grubunu oluşturmaktadır. VED analizi, ilaçların \%12,11'ini (51) ve toplam maliyetin $\% 17,14$ 'ünü $\mathrm{V}$ grubu, ilaçların \%59.38'ini (250) ve toplam harcamaların \%72,38'ini E grubu ve ilaçların \%28,51'ini (120) ve toplam harcamaların \%10,48'ini D grubunu oluşturmaktadır. ABC-VED matris analizinde ise, ilaçların \%22,09'unu (93) ve toplam maliyetin \%74,21'ini kategori I, ilaçların \%54,63'ünü (230) ve toplam harcamaların \%22,23'ünü kategori II ve ilaçların \%23,28'ini (98) ve toplam harcamaların \%3,56'sin1 kategori III oluşturmaktadır. Sonuç olarak, kaynakların en iyi şekilde kullanılması ve hastane eczanesinde stokta kalmayan durumların ortadan kaldırılması için rutin bir uygulama olarak benimsenmesi gerekmektedir. ${ }^{6}$

Anand ve arkadaşları (2013), Delhi'deki bir Tıp Koleji'nin Toplum Hekimliği Bölümünde yaptıkları çalıșmalarında, 20102011 yılları arasında kullanılan 129 adet ilacın ABC yöntemi, VED yöntemi ve ABC VED matris yöntemi kullanmışlardır. 129 adet ilaç yapılan toplam yıllık ilaç harcaması $4,35,847,85$ rupi bulunmuştur. ABC yöntemi, 129 adet ilacin \%18,6's1 ve ilaç tüketimlerinin \%69,1'ini A grubu ilaçlar oluşturmaktadır. İlaçların \%24,0'ü ve ilaç tüketimlerinin \%20,8'ini B grubu ve ilaçların \%57,4'ü, ilaç tüketimlerinin \%10,1'ini C grubu ilaçlar oluşturmaktadır. VED analizi sonuçları ise 129 adet ilacın \%13,2'si ve yıllık ilaç tüketimlerinin \%18,7'sini V grubunu oluşturmaktadır. Toplam ilaçların $\% 38,8$ 'i, y1llık ilaç tüketimlerinin ise $\% 49,5$ 'ini E grubunu ve ilaçların \%48,0'i, yıllık ilaç tüketimlerinin $\% 31,8$ 'i D grubuna ait ilaçlardır. ABC-VED matris yönteminin sonuçlarına bakıldığında, kategori I' de 37 ilaç $(\% 28,68)$, kategori II' de 53 ilaç $(\% 41,09)$ ve kategori III' te 39 ilaç $(\% 30,23)$ tespit edilmiştir. Sonuç olarak ise, ilaç stokunun verimli bir şekilde yönetimi sadece hasta bakımında değil aynı zamanda kaynakların optimal düzeyde kullanımına katkıda bulunduğu için stok kontrol yöntemlerine ihtiyaç olmaktadır. ${ }^{7}$

Yiğit çalışmasında (2014), Akdeniz Üniversitesi Hastanesi Eczane bölümünde yaptığı çalışmasında yıllık ilaç harcamalarının $\mathrm{ABC}$ ve VED analiz yöntemleriyle analiz etmek hedeflenmiştir. $\mathrm{Bu}$ çalışmada 1328 ilacın toplam maliyeti 23.205.114 TL'dir. ABC analizine göre, A 
grubunda yer alan 43 ilacın yıllık ilaç tüketim tutarının \%70,11'ini oluşturmaktadır. B grubunda bulunan 102 ilacin yillık toplam harcama maliyetinin \% 19,91'ini oluşturmakta ve C grubuna ait 1183 ilacın yıllık ilaç maliyetinin \%9.98'ini oluşturmaktadır. VED analizinde ise, ilaçların yaklaşık olarak \%25,15'i V grubu, $\% 52,48$ 'i D grubu ve \% 22,36's1 ise D grubu olarak ayrılmıştır. ABC-VED matris analizine göre 1.328 adet ilacin sınıflandırılması, 358 adet ilaç $(\% 22,47)$ kategori I, $700(\%$ 70,58) adet ilaç kategori II ve $270(\% 6,96)$ adet ilaç ise kategori III olarak bulunmuştur. Sonuç olarak, sağlık işletmelerinde kullanılan ilaçların etkin bir şekilde yönetilebilmesi için stok yönetim tekniklerine ihtiyaç oluşmaktadır. ${ }^{8}$

Singh ve arkadaşları (2015), sıkı bir şekilde yönetim kontrolü gerektiren ilaçların kategorilerini belirlemek için Kuzey Hindistan'daki üçüncü basamak bakım, eğitim, araştırma ve sevk enstitüsünün eczane bölümünün $\mathrm{ABC}$, VED ve $\mathrm{ABC}-\mathrm{VED}$ matris analizini yapmayı amaçlamışlardır. 2008-2009 ve 2009-2010 y1llarında eczanenin her bir ilaç kalemi için yapılan yıllık tüketim ve harcamalar incelenmiş ve stok kontrol yöntemleri yani $A B C, V E D$ ve ABC-VED matris analizi uygulanmıştır. Toplam ilaç sayıları 416 kalem (2008-2009 y1li) ve 379 kalem (2009-2010 y1l1) ve toplam harcamalar ise 2008-2009 yaklaş1k olarak 6.04 milyon rupi ve 2009-2010 yaklaşık olarak 4.84 milyon rupi oluşturmaktadır. Eczane bölümünün 20082009 y1lı ABC analizi göre, ilaçların 42 $(\% 11,23)$ ve toplam harcamaların \%70,19'unu A grubu, ilaçların $92(\% 24,6)$ ve toplam harcamaların \%19,83'ünü B grubu ve ilaçların $282(\% 75,4)$ ve toplam harcamaların $\% 9,98$ ' i C grubunu oluşmaktadır. VED analizi göre, ilaçların $46(\% 12,3)$ ve toplam harcamaların \%19,56 V grubu, ilaçların 230 $(\% 61,5)$ ve toplam harcamaların \%71,12'si E grubu ve ilaçların $98(\% 26,2)$ ve toplam harcamaların $\% 9,33$, ü D grubunu oluşturduğu tespit edilmiştir. Ancak 20092010 yılı için eczane bölümünün $\mathrm{ABC}$ analizi, ilaçların $42(\% 11,08)$ ve toplam harcamaların \%70,04'ü A grubu, ilaçların 84
$(\% 22,16)$ ve toplam harcamaların \%19,93'ü B grubu ve ilaçların $253(\% 6,75)$ ve toplam harcamaların \%10,02 $\mathrm{C}$ grubudur. VED analizi, ilaçların $47(12,4 \%)$ ve toplam harcamaların \%25,05' i V grubu, ilaçların $228(\% 60,16)$ ve toplam harcamalarin \%66,91'i E grubu ve ilaçların 104 (\%27,4 ve toplam harcamaların \%8,04'ü D grubunu oluşturduğu tespit edilmiş̧tir. ABC-VED matris analizine göre ise, 2008-2009 y1lı için kategori I' de ilaçların $80(\% 21,4)$ ve toplam harcamaların \%76,13' ü, kategori II' de ilaçların $218 \quad(\% 58,29)$ ve toplam harcamaların \%20,7'si ve kategori III ise 76 $(\% 20,3)$ ve toplam harcamaların $\% 3,18$ ' ini oluşturduğu tespit edilmiştir. 2009-2010 y11 için kategori I' de ilaçların $75(\% 19,79)$ ve toplam harcamaların \%74,86 kategori II' de ilaçların $218 \quad(\% 57,52)$ ve toplam harcamaların \%22,13'ü ve kategori III'te ise $86(\% 22,69)$ ve toplam harcamalarin \%3,00'ünü oluşturduğu bulunmuştur. Sonuç olarak, ABC-VED analizleriyle, hastane eczanesinde kaynakların uygun bir şekilde akılcı kullanımı ve stok dışı kalmasının ortadan kaldırılması için benimsenmelidir. ${ }^{9}$

Kumar ve Chakravarty (2015), Silahlı Kuvvetlerin üçüncü basamak eğitim hastanesinin tıbbi depolarının $A B C$ ve VED analiziyle, ilaç kategorilerini belirlemek için gerçekleştirildi. Araştırma kapsamında ele alınan 1536 maddeden sirasiyla \%6,77 (104), $\% 19,27$ (296) ve \%73,95 (1136) maddenin sirasiyla $\mathrm{A}, \mathrm{B}$ ve $\mathrm{C}$ kategorisinde maddeler olduğu tespit edilmiştir. VED analizi, V \%13.14 (201), E \%56.37 (866) ve D \%30.49 (469) olduğunu ortaya koymuştur. Envanterin ABC-VED matris analizi, kategori I' de yer alan 1536 ilaç envanterinden sadece 322'sinin (\%21) önemli bir şekilde dikkat edilmesi gerektiğini tespit edilmiştir. Kategori II' de ise, toplam ilaçların \%51,17 sini oluşturmaktadır. Kategori III ilaçların \%27,83' ünden (427) oluşmaktadır. Sonuç olarak, tıbbi depoların verimli yönetimi için bilimsel stok yönetimi araçlarının rutin olarak uygulanması gerekir, çünkü bu, sınırlı kaynakların makul kullanımına ve hasta bakımında iyileşmeye katkıda bulunmaktadır. ${ }^{10}$ 
Yılmaz (2018) çalışmasında amacı, ABCVED yöntemleriyle ilaçların yıllık tutarlarını analiz ederek, kurumun optimal ilaç stoklama düzeyine yardımcı olmaktadır. Bu sayede stok maliyetlerinin optimum seviyeye düşürmeyi hedeflenmiştir. $\mathrm{Bu}$ çalışmada, İstanbul'da faaliyet gösteren özel bir hastanenin 2016 y1lı ilaç tüketim verileri kullanılarak y1llık tüketim ve 910 kalem ilacın birim maliyetleri esas alınarak her bir ilacın toplam yıllık harcaması hesaplanmıștır. Yapılan ABC yöntemine göre, A grubu yillık ilaç tutarların \%70,08'i 46 ilaçtan, B grubu $\% 19,88$ 'i 92 ilaçtan ve $\mathrm{C}$ grubu \%10,04'ünden 772 ilaçtan oluşmaktadır. VED yöntemine göre, V'de 265 ilaç, E'de 467 ilaç D'de 178 ilaç olarak belirlenmiştir. ABC-VED matris yöntemine göre, kategori I' de 298, kategori II' de 446, kategori III' de 163 ilaç olduğu tespit edilmiştir. Sonuç olarak bu analizler, özellikle toplam harcamaların önemli bir bölümünü olușturan ilaçların güvenlik stok seviyelerinin belirlenmesinde yönetime katk1 sağlayacaktır. ${ }^{11}$

Işıkçelik ve arkadaşları (2019), çalışmada bir sağlık işletmesinin yıllık olarak ilaçlarını $\mathrm{ABC}, \mathrm{VED}$ analizi ve ABC-VED matrisiyle analiz etmek amaçlanmıştır. 2017 yılında hastaneye ait 355 adet ilacin y1llik toplam maliyetinin $1.041 .023,44 \mathrm{TL} \quad$ olduğu belirlenmiştir. $\mathrm{ABC}$ analizine göre, ilaçların \%12,39'u A sınıfinı, \%18,31'i B sınıfinı, $\% 69,30$ 'u ise C sınıfını; toplam ilaç maliyetinin \%70,46's1 A sinıfi, \%20.12'si B sınıfi, \%9,42'si ise C sınıfını oluşturduğu tespit edilmiştir. VED analizine göre, ilaç stoklarının \%36,34'ü V grubu, \%45,35'i E grubu ve \%18,31'inin D grubu; ilaçların toplam maliyetlerinin \%36,90'1 V grubu ilaçlardan, \%50,77'si E grubu ilaçlardan ve $\% 12,33$ 'ü D grubunu oluşturmaktadır. ABCVED matris analizine göre ise, toplam stok miktarının Kategori I' deki ilaçların \%44,23, kategori II' deki ilaçların \%42,53 ve kategori III' deki ilaçların \%13,24'tür. Toplam yıllık stok tutarının Kategori I' deki ilaçların $\% 80,52$, kategori II' de ilaçların \%17,49 ve kategori III' de ilaçların \%1,99'a sahip olduğu bulunmuştur. Sonuç olarak $\mathrm{ABC}$ analizinde ilaçların maddi açıdan sınıflandırılması, VED analize göre ilaçların hayati önem derecelerine göre siniflandirılması ve ABC-VED matris yöntemi ile ise kurumun stoklarının maddi açıdan ve hayati önem açısından değerlendirilmesinin sağlanmıştır. ${ }^{12}$

Koçyiğit ve Doğan Çulha (2020) yaptıkları çalışmada bu çalışmadan farklı olarak özel bir hastanenin acil servisinde değil genel yoğun bakım bölümünde kullanılan tıbbi sarf malzemelerinin kurum kasasından aldığı tutarı belirlemek ve sarf malzemelerin ABC-VED analizleriyle ve ABC-VED matrisiyle analiz etmeyi amaçlamışlardır. ABC analizi sonucuna göre A grubu yıllık malzeme maliyetinin \%69,50'sini kapsadı̆̆ 1 , \%20,25'inin B grubunu, \%10,26's1 ise C grubunda olduğu bulunmuştur. VED analizi ile toplam maliyetin $\% 79,44$ 'ünün $\mathrm{V}$ grubu, $\% 18,86$ 'sının E ve \%1,70'inin D gruplarında bulunan malzemeden oluştuğu bulunmuştur. ABC-VED matris analizine göre ise, toplam malzeme maliyetinin kategori I'de \%78,58, kategori II \%19,07 ve kategori III'te \%2,36 olduğu saptanmıştır. Sonuç olarak, sağlık işletmelerinde tıbbi malzeme stoklarının maliyetlerinin verimli bir şekilde yönetilmesi için ABC-VED analizleri ve ABC-VED matris analizlerinin sağlık işletmelerinde kullanılması önerilmektedir. ${ }^{13}$

\section{MATERYAL VE METOT}

\section{Araştırmanın Amacı ve Önemi}

$\mathrm{Bu}$ araştırmanın amacı; özel hastanelerin acil servislerinde tüketilen sarf malzemelerin ABC-VED analizi ve ABC-VED matris analiziyle kullanım tutarını ve miktarını tespit etmektir. Belirlenen amaca ulaşmak için Ankara'da faaliyet gösteren bir özel hastanenin acil servisinde araştırma yapılmıştır. 
$\mathrm{Bu}$ analizler kapsamında, kurumun stoklarının doğru bir şekilde takibinin yapılması ve yönetilmesi, stoklardaki kayılar, eksilmeler, deforme olmuş ve son kullanma tarihi geçmiş malzemeler gibi oluşabilecek düzensizliklerin önlenmesi, malzemelerin tüketim miktarlarının en aza indirilmesi, ihtiyacın üstünde malzeme alımlarının giderilmesi ve malzeme maliyetlerinin analiz edilmesi hedeflenmektedir.

Sağlı işletmeleri hizmet sektörleri arasında finans açısından maliyeti yüksek olan işletmelerdir. Bu maliyetlerin önemli bir kısmını ise, sağlık işletmelerinin tıbbi cihazları ve malzemeleri yani stokları oluşturmaktadır. Sağlık işletmelerinde bulunan bu stokların etkin ve verimli bir şekilde yönetilmesi ve kontrolünün sağlanması önemlilik arz etmektedir.

Bu çalışmanın önemi, Türkiye'de bir özel hastanenin acil servis bölümünde kullanılan tıbbi sarf malzemelerin analiz edilmesi, diğer hastaneler açısından örnek alınabilecek bir uygulama olması ve literatürdeki sınırlı çalışmalara katkı sağlamasıdır.

\section{Araştırmanın Etik Yönü}

$\mathrm{Bu}$ çalışmaya, Ankara'da özel bir hastanenin Etik Kurulundan (05/03/2019-33 tarih-sayı) yazılı izin alınarak başlanılmıştır.

\section{Araştırmanın Evreni ve Örneklemi}

Araştırma Ankara'da bulunan bir özel hastanenin 2019'da aldığ tıbbi sarf malzemeleridir ve evrenin tamamına ulaşılmıştır.

\section{Araştırmanın Yöntemi}

Araştırma, Ankara'da bulunan özel hastanenin acil servis bölümü 2019 y1lı stok hareketleri içindeki malzeme tüketim miktarlarının değerlendirilmesi ve incelenmesi aracılığıyla gerçekleştirilmiştir. İlgili veriler hastane bilgi yönetim sisteminden alınmış ve her bir malzeme miktarı ve birim fiyatları MS Excel'e aktarılmıştır. Her bir malzemenin yıllık harcama maliyetinin büyükten küçüğe doğru siralanarak kümülatif yüzdeleri hesaplanmıştır. Araştırmada aşağıda belirtilen stok kontrol yöntemleriyle veriler analiz edilmiştir.

ABC Analizi, mevcut stokların sinıflandırılması yıllık tüketim ve malzemelerin y1llık değerine dayanmaktadır. Malzemelerin bu y1llık tüketim maliyetinin azalan şekilde düzenlenmesi ile siniflandirılmaktadır. ${ }^{14} \mathrm{Bu}$ siniflandirma tekniği, stok sistemindeki diğer malzemelere göre yüksek değerli ve tüketimi yüksek malzemelere odaklanarak yöneticilerin seçici bir şekilde stok kontrolü gerçekleştirmesine yardımc1 olan bir teknik olarak ifade edilmektedir. Birçok işletme $\mathrm{ABC}$ sınıflandırılma tekniğini kullanmaktadır. Yüksek değerli malzemelerin az sayıda (genelde stoktaki malzemelerin \%10'u) olanlarını s1k1 kontrol, stokun \%20'sini kapsayan malzemeler orta düzey de kontrol ve en düşük değerli malzemeler (genelde stoktaki malzemelerin \%70'i) basit düzeyde kontrol edilmesi gerekmektedir. "15-12-16"

VED Analiz, bir kalemin kritikliğini ve üretim ve diğer hizmetler üzerindeki etkisini belirlemek için yapılır. Yedek parçaların sınıflandırılmasında özel olarak kullanılır. Eğer bir parça hayati önem taşıyorsa, ona ' $\mathrm{V}$ ' sinıflandırması verilir, eğer gerekliyse ' $E$ ' sınıflandırması verilir ve o kadar önemli değilse, parçaya 'D' sınıflandırması verilir. $V$ kalemleri için genellikle büyük bir stok stoku korunurken, D kalemleri için minimum stok yeterlidir. $^{17}$

ABC-VED matris yöntemi, $A B C$ ve VED analizinin birleşmesi ile oluşan sınıflandırma biçimidir. Kategori I (AV, BV, CV, AE, $\mathrm{AD}$ ), tüm hayati ve pahalı malzemeler olduğundan iyi bir şekilde yönetilmesi ve stok kontrolünün yapılması gerekmektedir. Kategori II (BE, CE, BD), sağlık hizmeti sunumu süresinde gerekli olan orta düzeyde olan malzemelerdir ve $\mathrm{E}$ ve $\mathrm{B}$ gruplarının kalan öğelerini kapsamaktadır. Kategori III (CD), ise malzeme maliyetlerinin düşük olduğu isteğe bağlı olan malzeme grubunu içermektedir. ${ }^{6-8}$ 


\section{Sinırlılıkları}

Araştırma hastane bilgi yönetim sisteminden alınan verileriyle uzmanların araştırmada verdikleri bilgiler gerçek ve doğru olarak varsayılmıştır.

$\mathrm{Bu}$ çalışma, Ankara ilinde faaliyet gösteren özel bir hastanede yapılmıştır. Bu hastanenin hem büyük olması hem de birden çok depo biriminin bulunmasından dolayı sadece acil servis bölümüne ait verilerden yararlanılmıştır. Araştırmanın kapsamında sadece trbbi sarf malzemeler inceleme kapsamına alınmıştır.

$\mathrm{Bu}$ araştırma, Ankara ilinde bir özel hastane ve tıbbi sarf malzemeler ile sınırlandırıldığından dolayı araştırma sonuçları genellenemez.

\section{BULGULAR}

\section{Genel Bilgiler}

Ankara ilinde iki ayrı şubesi bulunan hastane, 9 yıldan beri sağlık hizmeti vermektedir. Hastanenin iki şubesinde yaklaşık 250 doktor, 1350'ye yakını hemşire ve destek sağlık personeli oluşturmakta ve toplam 301 yatak kapasitesi, 71 yoğun bakım, 31 yenidoğan yoğun bakım yatağına sahiptir. Hastanenin araştırmaya alınan şubesi $40.000 \mathrm{~m} 2$ alana sahiptir ve hastaneye Acil servis bölümüne ait 01.01.2019 ve 31.12.2019 tarihleri arasında kullanılan 185 adet malzeme değerlendirme kapsamına alınmakta ve aynı tarihler arasında bu malzemelerin maliyeti ise $€ 127.081,17$ 'dir.

\section{ABC Analizi ile Elde Edilen Bulgular}

ABC analizi sonucunda elde edilen bulgular, ABC siniflarında yer alan malzeme sayıları ve bunların yıllık tüketim içerisindeki oranları tablo 1'de verilmiş ve hastanenin acil servisinde kullanılan en yüksek maliyeti olan ilk on malzemesinin y1llk maliyeti ve oranları şekil 1'de sıralanmıştır.

Tablo 1. ABC Analiz Tablosu

\begin{tabular}{cccccc}
\hline ABC & $\begin{array}{l}\text { Malzeme } \\
\text { Sayısı }\end{array}$ & $\begin{array}{c}\text { Toplam } \\
\text { Tüketim } \\
\text { Miktarı }\end{array}$ & $\begin{array}{c}\text { Malzeme } \\
\mathbf{( \% )}\end{array}$ & $\begin{array}{c}\text { Tutar } \\
(\mathbf{( t )})\end{array}$ & $\begin{array}{c}\text { Tutar } \\
(\boldsymbol{\%})\end{array}$ \\
\hline A sinıfi & 23 & 213.448 & 12,44 & $88.054,53$ & 69,29 \\
\hline B sinıfi & 27 & 49.234 & 14,59 & $26.167,48$ & 20,59 \\
\hline C sinıfi & 135 & 40.984 & 72,97 & $12.859,17$ & 10,12 \\
\hline Toplam & $\mathbf{1 8 5}$ & $\mathbf{3 0 3 . 6 6 6}$ & $\mathbf{1 0 0}$ & $\mathbf{1 2 7 . 0 8 1 , 1 7}$ & $\mathbf{1 0 0}$ \\
\hline
\end{tabular}

Tablo 1'e göre, 2019 yılında kullanılan 185 adet malzemenin maliyeti £127.081,17'dir. Bunların 23 adet malzemenin y1llık maliyeti £88.054,53 ile A sinıfina aittir. B sinıfı malzemeler ise 27 adet ve yıllık toplam maliyeti $¥ 26.167,48$ ve $C$ sinifinda olan 135 adet malzeme maliyeti de $€ 12.859,17$ olarak bulunmuştur.
Tablo 1'de toplam malzeme miktarı ve yıllık maliyet tutarı açısından incelendiğinde A grubunda bulunan malzemelerin \%12,44 toplam y1llik maliyetin \%69,3'ünü oluşturmaktadır. B grubundaki malzemeler ise yıllık toplam harcama maliyetinin $\% 20,6$ 'sın1 oluşturmaktadır. C grubunda bulunan malzemeler ise toplam malzemelerin (\%73) yıllık maliyet tutarının \%10,1'ini kapsadığı tespit edilmiştir. 


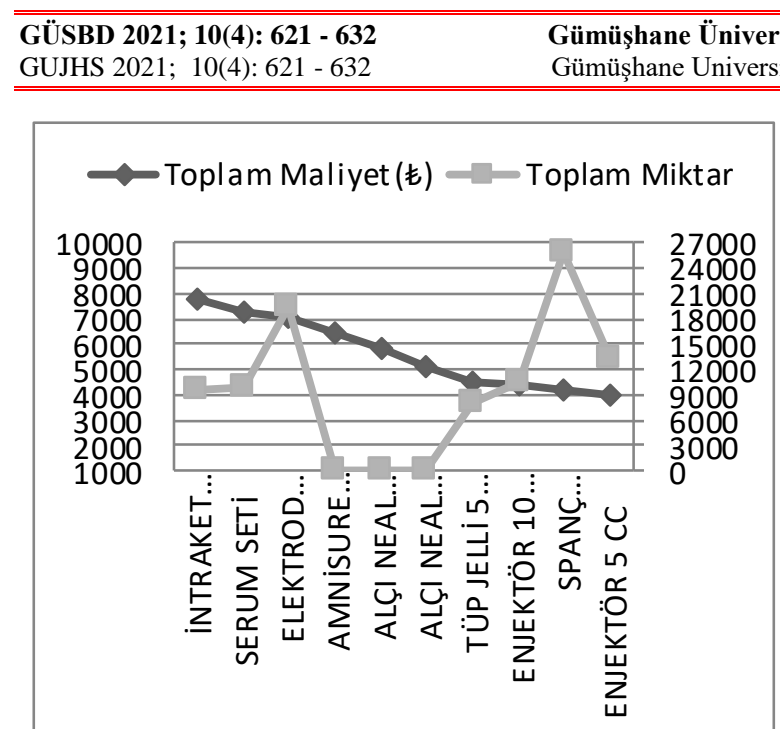

Şekil 1. Malzeme İsimlerine Göre Toplam Maliyet Ve Toplam Miktar Dağılımı

Şekil 1 incelendiğinde kullanılan en yüksek maliyeti olan malzeme intraket no:20 pembe ve maliyeti $€ 7.787,87$ olup, toplam malzeme maliyetinin $\% 6,13$ 'ünü oluşturmaktadır. Diğer malzemeler ise sirasiyla; serum seti, elektrod ekg f55, amnisure rom test, alçı neal splınt atel 4", alçı neal splınt atel 5", tüp jelli $5 \mathrm{ml}$ sarı, enjektör 10 cc $3 p$ yeşil, spanç $7.5 \times 7.5 \mathrm{~cm} 12$ kat, enjektör 5 cc $3 p$ yeşil olarak görülmüştür.

\section{VED Analizinden Elde Edilen Bulgular}

Tablo 2'de VED analizine göre malzemelerin sayıları ve malzemelerin yıllık tüketim maliyetlerinin gruplara yüzde dağılımı verilmiştir.

Tablo 2. VED Analiz Tablosu

\begin{tabular}{|c|c|c|c|c|c|}
\hline VED & $\begin{array}{c}\text { Malzeme } \\
\text { Sayısı }\end{array}$ & $\begin{array}{l}\text { Toplam } \\
\text { Tüketim } \\
\text { Miktarı } \\
\end{array}$ & $\begin{array}{c}\text { Malzeme } \\
(\%)\end{array}$ & $\underset{(\mathbf{E})}{\text { Tutar }}$ & $\begin{array}{c}\text { Tutar } \\
(\%)\end{array}$ \\
\hline V grubu & 84 & 170.552 & 45,40 & $98.513,17$ & 77,5 \\
\hline E grubu & 68 & 64.583 & 36,75 & $21.648,65$ & 17,1 \\
\hline D grubu & 33 & 68.531 & 17,85 & $6.919,35$ & 5,4 \\
\hline Toplam & 185 & 303.666 & 100 & 127.081,17 & 100 \\
\hline
\end{tabular}

Tablo 2'ye göre malzemelerin miktarlarının yüzde olarak dağılımı $\mathrm{V}$ grubu 84 kalem \%45,40, E grubu 68 kalem \%36,75 ve D grubu 33 kalem malzemeler ise $\% 17,85$ olarak tespit edilmiştir. VED'e göre, malzemelerin yıllık tüketim maliyeti ise, $\mathrm{V}$ grubu malzemelerin toplam y1llı tüketimin \%75,5’i (€98.513,17), E grubu malzemeler için \%17,1’i (‡21.648,65) ve D grubu malzemeler için \%5,4’ü (‡6.919,35) olarak tespit edilmiştir.

Tablo 2'ye göre, toplam malzeme miktarı ve yıllık maliyet tutarı açısından $\mathrm{V}$ grubunda bulunan toplam malzemeler $(\% 45,4)$ y1llik maliyet tutarı toplaminın \%77,5'ini oluşturmaktadır. E grubundaki malzemeler $(\% 36,75)$ ise maliyet tutarı olarak toplam tutarın \%17,1'ini oluşturmaktadır. C grubunda bulunan malzemeler ise toplam malzemelerin $(\% 17,8)$ yıllık maliyet tutarının $\% 5,4$ ' ünü olușturduğu görülmüştür.

\section{ABC - VED Matris Analizi ile Elde Edilen Bulgular}

ABC-VED matris analizini göstermektedir. Bu analiz kullanılarak dokuz farklı alt kategori (AV, $\mathrm{AE}, \mathrm{AD}, \mathrm{BV}, \mathrm{BE}$, $\mathrm{BD}, \mathrm{CV}, \mathrm{CE}$ ve $\mathrm{CD}$ ) incelenmiştir. Bu dokuz grup ayrica I, II ve III kategorileri olmak üzere üç ana kategoriye ayrılmıştır. 
Tablo 3. ABC-VED Analizi

\begin{tabular}{|c|c|c|c|c|c|c|c|c|c|c|c|c|c|c|c|c|}
\hline \multirow{2}{*}{$\begin{array}{l}\text { ABC } \\
\text { VED }\end{array}$} & \multicolumn{4}{|c|}{$\mathbf{V}$} & \multicolumn{4}{|c|}{$\mathbf{E}$} & \multicolumn{4}{|c|}{ D } & \multicolumn{4}{|c|}{ Genel Toplam } \\
\hline & Miktar & $\%$ & TutarE & $\%$ & Miktar & $\%$ & TutarE & $\%$ & Miktar & $\%$ & TutarE & $\%$ & Miktar & $\%$ & TutarE & $\%$ \\
\hline $\mathbf{A}$ & 18 & 9,7 & $78.583,42$ & 61,8 & 2 & 1,1 & $6.138,86$ & 4,8 & 1 & 0,5 & $3.332,25$ & 2,6 & 21 & 11,3 & $88.054,53$ & 69,3 \\
\hline B & 14 & 7,6 & $13.213,60$ & 10,4 & 10 & 5,4 & $10.613,76$ & 8,4 & 3 & 1,6 & $2.340,12$ & 1,8 & 27 & 14,6 & $26.167,48$ & 20,6 \\
\hline $\mathbf{C}$ & 52 & 28,1 & $6.716,15$ & 5,3 & 56 & 30,3 & $4.896,04$ & 3,9 & 29 & 15,7 & $1.246,97$ & 1,0 & 137 & 74,1 & $12.859,16$ & 10,1 \\
\hline $\begin{array}{c}\text { Genel } \\
\text { Toplam }\end{array}$ & 84 & 45,4 & $98.513,16$ & 77,5 & 68 & 36,8 & $21.648,66$ & 17,0 & 33 & 17,8 & $6.919,35$ & 5,4 & 185 & 100 & $127.081,17$ & 100,0 \\
\hline
\end{tabular}

Tablo 3'e göre malzemelerin maliyetini ve hayati öneme sahip olup olmamasına göre ABC-VED Matrisi analizi yapılmıştır. Analiz sonucuna da en yüksek maliyeti bulunan ve hastanede bulunmasi zorunlu ya da hayati öneme sahip olan AV gurubunu oluşturan malzeme miktarı 18 kalem, tüm stokların $\% 9,7$ 'lik kısmını ve toplam maliyetin de \%61,8'lik (£78.883,42) k1smını oluşturmaktadır. Stok değeri yüksek ancak benzerleri bulunan $\mathrm{AE}$ grubu malzeme miktarı 2 kalem, tüm stokların 1,1'lik kısmını ve toplam maliyetin \%4,8‘lik (£6.138,86) kısmını oluşturmakta ve stok maliyeti yüksek ancak hastanede zorunlu olarak bulunması gerekmeyen ya da isteğe bağlı bulundurulan $\mathrm{AD}$ grubu malzemeler ise 1 kalem toplam stok miktarının \%0,5'ini ve toplam maliyetin $\% 2,6$ 'sını (£3.332,25) oluşturduğu tespit edilmişstir.

Malzeme maliyetinin orta düzeyde olan ancak hastanede bulunması zorunlu olan BV grubu malzeme sayıs 14 kalem ve stok miktarının \%7,6'sını oluşturmakta ve toplam maliyetin 10,4'ünü (£13.213,60) oluşturmaktadır, Stok maliyet tutarı orta düzeyde ve hastanede benzerleri bulunabilen BE grubu malzeme sayıs 10 kalem toplam miktarın \%5,4'ünü ve toplam maliyetin \%8,4'ünü (£10.613,76) oluşturmaktadır. Maliyet tutarı orta hastanede zorunlu olarak bulunmaması gereken BD grubu malzemeler ise 3 kalem ve stok miktarının \%1,6'sını kapsamakta ve toplam maliyetin \%1,8'ini (£2.340,12) oluşturduğu bulunmuştur.
Maliyetin en az olduğu fakat hastanede zorunlu olarak bulunması gereken, $\mathrm{CV}$ grubu malzeme sayısı 52 kalem, stok miktarının $\% 28,1$ 'lik k1smını ve toplam maliyetin \%5,3'lük (£6.716,15) kısmını oluşturmaktadır. Stok maliyet en az fakat hastanede bulunmasi zorunlu olmayan ve benzenlerinin bulunabileceği $\mathrm{CE}$ grubu malzeme sayısı 56 kalem ve stok miktarının 30,3'lük (‡4.896,04) kısmını kapsamakta ve toplam maliyetin \%3,9'luk k1sminı oluşturmaktadır. Maliyeti en az fakat isteğe bağlı olarak bulundurulan CD grubu malzemelerin sayıs 29 kalem ve stok miktarının \%15,7'lik kısmını kapsamakta ve toplam maliyetin \%1'lik (£1.246,97) kısmını oluşturduğu tespit edilmiştir.

Hastanede bulunması zorunlu olan veya bulundurulmamasi sonucunda hayati olumsuzluklara neden olan malzemelerin miktarı 84 kalem ve stok miktarının \%45,4'e karşılık gelmekte ve toplam maliyetin \%77,5'ini (£98.513,16) kapsamaktadır. Hastanede orta düzeyde öneme sahip olan ya da muadillerin bulunun malzemelerin miktarı ise 68 kalemdir ve stok miktarının \%36,8'lik kısmını ve toplam maliyetin \%17'lik kısmını oluşturmaktadır.

Hastanede bulunması zorunlu olmayan ya da isteğe bağlı olarak bulundurulması gereken malzemeler ise 33 kalem ve stok miktarının \%17,8'ini kısmını ve toplam maliyetin \%5,4'lük (£6.919,35) kısmını kapsadığ 1 tespit edilmiştir. 
Tablo 4. ABC-VED Matris Analizi

\begin{tabular}{clccccc}
\hline Kategori & \multicolumn{1}{c}{$\begin{array}{c}\text { Birleştirilmiş } \\
\text { Kategori }\end{array}$} & $\begin{array}{c}\text { Malzeme } \\
\text { Sayısı }\end{array}$ & $\begin{array}{c}\text { Yıllık } \\
\text { Tüketim } \\
\text { Miktarı }\end{array}$ & $\begin{array}{c}\text { Malzeme } \\
(\mathbf{\%})\end{array}$ & Tutar (£) & $\begin{array}{c}\text { Tutar } \\
(\boldsymbol{\%})\end{array}$ \\
\hline I & AV, AE, AD, BV, CV & 87 & 235.520 & 47,03 & $115.265,63$ & 90,70 \\
\hline II & BE, CE, BD & 69 & 56.033 & 37,30 & $10.568,57$ & 8,31 \\
\hline III & CD & 29 & 12.113 & 15,67 & $1.246,97$ & 0,99 \\
\hline \multirow{2}{*}{ Toplam } & $\begin{array}{l}\text { AV, AE, AD, BV, } \\
\text { CV, BE, CE, BD, CD }\end{array}$ & $\mathbf{1 8 5}$ & $\mathbf{3 0 3 . 6 6 6}$ & $\mathbf{1 0 0 , 0 0}$ & $\mathbf{1 2 7 . 0 8 1 , 1 7}$ & $\mathbf{1 0 0}$ \\
\hline
\end{tabular}

$A B C$ ve $V E D$ analizinin bir birleștirilmesi sonucunda, hastanede bulundurulması zorunlu, maliyeti yüksek ve hayati önem taşıdığından dolayı üst yönetim kontrolünün de bulunmasinı gerektiren malzemeler kategori I'e ait olan 87 kalem malzemenin stok miktarının yaklaşık yarısını oluşturduğu görülmektedir. $\mathrm{Bu}$ malzemelerin yıllık maliyetleri \%90,70'ini kapsamaktadır. Kategori II ise 69 kalem olup stok miktarının $\% 37,30$ 'luk kismını ve toplam y1llık maliyetin \%8,31'lik kısmını olușturmaktadır. Kategori III 29 adet malzemeden oluşmakta ve stok miktarının \%15,67'sini kapsamakta ve toplam yıllık maliyetin \%0,99'luk kısmını oluşturduğu tespit edilmiştir.

\section{SONUÇ VE ÖNERİLER}

$A B C$ ve VED matris analizine göre I' inci kategoride bulanan 87 adet malzemenin hizmet sunumu sirasinda bulunmaması durumunda hastalara verilen hizmetin aksamasına, hizmet kalitesinin düşmesine hatta hastanın sağlığını daha kötüye gitmesine neden olacaktır. Bu kapsamda bu malzemelerin ihtiyac halinde kullanılabilir durumda olması yani hazır bir şekilde bulundurulması gerekmektedir. Maliyeti yüksek değere sahip olan bu malzemeler için öncelikli olarak ve dikkatli bir şekilde yönetim kurulunun denetiminden ve kontrolünden geçmesi gerekmektedir.

Stok takibinin yapılabilmesi için uzman personellerin bulundurulması, takibin s1k1 ve dikkatli bir şekilde yapılması ve acil servis de kullanilan bu 87 adet malzemenin sayımlarının ayda bir yapılması; stoklardaki kayıpları ve eksilmeleri, stoklarda oluşan düzensizlikleri önceden belirlemeye ve önlemeye katkı sağlayacak ve stok maliyetlerinin artmasına engel olacaktır.

$\mathrm{Bu}$ malzemelerin tedarik süreçlerinin iyi yönetilmesi ve hangi malzemelerden ne miktarda tedarik edileceğinin belirlenmesi için etkili ve verimli bir stok kontrol yönteminin kullanılması oldukça önemlidir. Tedarikçiler ile olan anlaşmazlıklar halinde ya da malzemelerin tedarik süreçlerinin aksaması ya da kesintiye uğraması durumunda güvenlik stoklarının oluşturulması gerekmektedir. Bunların sonucunda ise, hizmet sunumunda kesintisiz bir şekilde, sürekli, etkili ve verimli bir hizmet sunumu sağlanacak ve yüksek maliyeti olan malzemelerin harcamaları kontrol altına alınacaktır.

Kategori II' de bulunan 69 kalem malzemenin hizmeti sunumu sirasinda bulunması gereken ve stok kontrolünün orta düzeyde yapılması gerekli olan malzemelerdir. $\mathrm{Bu}$ kategoride yer alan malzemeler tutar ve önem acisindan orta düzeyde bir öneme sahiptir. Ancak bu malzemeler hem stok miktarlarının artmasına hem de maliyet artıșına neden olacaktır. Bundan yüzden bu grupta yer alan malzemelerin hizmet sunumunun kesintiye uğramaması için daha etkin bir șekilde yönetilebilmesi ve güvenlik stoku düzeylerinin de orta düzeyde tutulması gerekmektedir.

Kategori III'te yer alan 29 adet malzeme ise, hizmet sunumu sirasinda herhangi bir hayati öneme sahip olmayan ve maliyeti düşük olan malzeme grubudur. Doktorların isteklerine göre bulundurulan stoklardır. 
Güvenlik stokunun oluşturulmasına gerek olmayacaktır.

Sonuç olarak ABC-VED analizleri ile ABC-VED matris analizinin sağlık işletmelerinde kullanılması, yöneticiler açısından malzeme inceleme zamanlarını akıllıca yönetmelerine olanak sağlaması ve bu yöntem ile malzemelerin maliyeti ve tüketimi acısından en büyük etkiye sahip olan stok kontrolünü yapmak daha da kolaylaşacaktır. Stokların en uygun şekilde kullanımı, stok maliyetlerinin en aza indirilmesi, stok kontrolünde en çok dikkat edilmesi gereken malzemelerin sınıflandırılması, kesintisiz malzeme alımı, ihtiyacın üstünde malzeme tedariklerinin giderilmesi ve sağlık hizmeti sunumu sırasında oluşabilecek sorunların önlenmesinde yardımcı bir araç olarak kullanılabilecektir.

Yapılan çalışmadaki sonuçlara göre aşağıdaki önerilerde bulunulabilir;

- Maliyeti yüksek ve hayati önem taşıyan stokların etkili bir şekilde yönetilmesi malzeme maliyetlerinin azalmasına katkıda bulanacağı öngörülmektedir.

- Stokların stok kontrol yöntemleri ile incelenmesi sağlık işletmesinin malzemelere yapacağı yatırım kaynaklarını etkili ve verimli bir şekilde kullanılmasına katkı sağlayacaktır.

- Etkili bir stok yönetim süreci için malzeme yönetiminde hem satın alma biriminin hem de yönetim kurulunun katkıda bulunması önerilmektedir.

- Satın alma biriminin aynı kalem malzeme için birden fazla tedarikçi firmalardan fiyat teklifleri alması stok maliyetlerinin düşürülmesine katkı sağlayacaktır.

- Fazla stok bulundurma ya da hatalı ve fazla malzeme kullanımından kaçınılmasının stok maliyetlerini düşüreceği öngörülmektedir.

- Stok kontrolünde kategori I' de bulunan malzemelerin kategori II ve kategori III' deki malzemelere kiyasla malzemelerin planlanması, tedarik edilmesi çok dikkat edilmesi gerektiği öngörülmektedir.

- Kullanılan malzemelerin hasta üzerine hastane bilgi yönetim siteminden (HBYS) düşürülmesi ve özelikle maliyeti çok yüksek olan malzemelerin kullanıldıktan hemen sonra hastaya çıkılmasının sıkı bir şekilde takibinin yapılması gerekmektedir.

- Stoklar hakkında tüm çalışanlara eğitim verilmeli ve böylece hatalı malzeme kullanımının önlenmesi önerilmektedir.

- Hayati önem taşıyan malzemeler için güvenlik stoklarının oluşturulması ve sürekli olarak kontrol edilmesi gerekmektedir.

- Malzemelerin depolanmasinda kolayca bulunabilmesi için, alfabetik bir sıralama ya da malzemelerin kullanım alanlarına göre depolanması önerilmektedir.

- Tüm malzemelerin HBYS üzerinden minimum ve maksimum seviyelerinin belirlenmesi ve sisteme tanımlanması gerekmekte ve böylece belirlenen seviyelerin altına düşen malzemelerin satın alma süreçlerinin hılanması ve malzemenin tamamen bitmesini engelleyeceği önerilmektedir. 


\section{KAYNAKLAR}

1. Söyük, S. ve Gün, İ. (2018). Sağlık İşletmeleri Yönetiminde Temel Boyutlar Rehberi. İstanbul: Beta Yayıncılık.

2. Kiracı, M. (2009). "Stok Yönetimi ve Karlılık İlișkisinin Finansal Oranlar Aracılığıyla İncelenmesi: İMKB İmalat Sektöründe Bir Araștırma', ODTÜ Gelișme Dergisi, 36 (1), 161-195

3. Horngren, T.C, Datar, M.S. and Rajan, V.M. (2011). Cost Accounting A Managerial Emphasis. New Jersey: Prentice Hall

4. Tekin, M. (2018). Üretim Yönetimi. Konya: Günay Ofset Kitapları

5. Paramasivan, C. and Subramanian, T. (2009). Financial Management. New Delhi: New Age International (P) Limited publishers.

6. Devnani, M, Gupta, A.K. and Nigah, R. (2010). “Abc and VED Analysis of The Pharmacy Store of A Tertiary Care Teaching, Research and Referral Healthcare Institute of India”. Young Pharmacists Magazine, 2 (2), 201-205.

7. Anand, T, Ingle, G.K, Kishore, J. and Kumar, R. (2013). "ABC-Ved Analysis of A Drug Store in The Department of Community Medicine of A Medical College in Delhi", Indian. Journal of Pharmaceutical Sciences, 75 (1), 113

8. Yiğit, V. (2014). "Hastanelerde Stok Kontrol Analizi: Akdeniz Üniversitesi Hastanesinde Bir Uygulama'. Sayıştay Dergisi, 93, 105-128.

9. Singh, S, Gupta, K.A, Latika. and Devnani, M. (2015). “ABC and VED Analysis of The Pharmacy Store of A Tertiary Care, Academic Institute of The Northern India to Identify
The Categories of Drugs Needing Strict Management Control'. Journal of Young Pharmacists, 7 (2), 76-80.

10. Kumar, S.M. and Chakravarty, A.B. (2015). "ABC and VED Analysis of Expendable Medical Stores at A Tertiary Care Hospital". Medical Journal Armed Forces, 71 (1), 24-27.

11. Yilmaz, F. (2018). "The Drug Inventories Evaluation of Healthcare Facilities Using ABC and VED Analyzes". Journal of Pharmacy, 48 (2), 43-48.

12. Işıkçelik, F, Özkan, O. ve Ağırbaş, İ. (2019). "Hastane İlaç Stoklarının ABC, VED ve ABC-VED Yöntemleri İle Analizi”. Hacettepe Sağlık İdaresi Dergisi, 22 (2), 305-318.

13. Koçyiğit, S. ve Çulha, D.E. (2020). "Hastanelerde Stok Kontrol Faaliyetlerinin ABC ve VED Analizleriyle Değerlendirilmesi: Bir Özel Hastane Örneği”. Muhasebe ve Denetime Bakış, 20 (60), 37-56.

14. Kumar, A.S. and Suresh, N. (2008). Production and Operations Management. New Delhi: New Age International Publishers.

15. Shenoy, D. and Rosas, R. (2018). Problems and Solutions in Inventory Management. Cham: Springer International Publishing.

16. Gupta, R, Gupta, K.K, Jain, B.R a. and Garg, R.K. (2007) "ABC and VED analysis in medical stores inventory control”. Medical Journal Armed Forces India, 63 (4), 325327.

17. Alex, K. (2012). Cost Accountıng. New Delhi: Pearson Education. 